\title{
Narrative Charms in Late Medieval and Early Modern Wales
}

\author{
Katherine Leach \\ Harvard University, Department of Celtic Languages and Literature, USA
}

\begin{abstract}
In this article I will consider the general development of Welsh narrative charms from the earliest examples (late fourteenth century) up to the first decades of the Early Modern Era in Wales (mid-to-late sixteenth century). I will focus on the most common narrative charm types of this time: those that feature the motifs of Longinus, the Three Good Brothers, and Flum Jordan or Christ's birth in Bethlehem. The development of these charms over time can provide insights into changing attitudes in Wales towards healing, religion, superstition, and even language. By the onset of the Early Modern era, Welsh narrative charms were increasingly subject to rhetorical expansions of the religious narratives that constituted the efficacious component of the charm. Additionally, by the end of the fifteenth century and into the early sixteenth, charms that once commonly featured Latin as the predominant language demonstrated an increased preference for the vernacular. ${ }^{1}$
\end{abstract}

Keywords: Celtic Studies, Welsh, charming, healing, narrative charms, medieval, early modern

\section{INTRODUCTION}

In 1594, Gwen ferch Ellis became the first person in Wales executed for witchcraft. ${ }^{2}$ Known locally as a healer, it was Gwen's association with healing charms that played a part in implicating her in the charges of witchcraft. The evidence against Gwen included a Welsh charm, apparently written backwards, found inside the home of a prominent local family engaged in a dispute with a woman connected to Gwen. When asked by the court if she used charms, Gwen admitted to charming in order to heal sick men,

\footnotetext{
1 Thank you to Catherine McKenna, Harvard University, and Barry James Lewis, School of Celtic Studies at the Dublin Institute for Advanced Studies, for numerous insights and assistance with the development of this paper. Additionally, I am grateful to Michaela Jacques, Harvard University, and Joseph Shack, Harvard University, for reading early versions, and for very helpfully checking translations. Any mistakes are my own.

2 For more on Gwen's trial, along with trial documents of other witchcraft and witchcraft related legal cases in Wales, see Suggett 2019. See also Suggett 2008.
} 
women, and children, along with animals. Another piece of evidence used against her was her proven ownership of at least one copy of the Gospel of John, which was itself often used as a charm. ${ }^{3}$ Nearly a century before Gwen obtained her copy, the In principio of the Gospel of John was recorded into at least two separate Welsh manuscripts in a way that clearly indicates that these texts functioned as healing charms. ${ }^{4}$ Cases such as Gwen's demonstrate the idiosyncratic ways in which healing practices were regarded throughout history as well as the instability of the boundaries between medicine, magic, and religion. During Gwen's lifetime - the first decades of the Early Modern Era in Wales - healing charms were routinely copied into manuscripts that featured medical writing, religious works, and other poetry and prose. For Gwen, however, association with certain healing charms led to her conviction and ultimate death. ${ }^{5}$ In general, the charms of this epoch display remarkable continuity from the charms of medieval Wales, although their structure and function were adapted to a considerable degree - most noticeably over the course of the later fifteenth century and into the sixteenth century. This article will present some of the most commonly used narrative charms from later medieval Wales up to the beginning of the early modern era, taking into consideration the ways in which the structure and function of narrative charms changed over the course of the fifteenth and sixteenth centuries. ${ }^{6}$ It is fairly clear that the later narrative charms appearing in Welsh manuscripts display a propensity for expanded rhetoric within the biblical narrative while also demonstrating a decline in the inclusion of Latin as the fifteenth century draws to a close and the sixteenth century commences. ${ }^{?}$

Narrative charms most often feature historiolae: short narratives about Christ, saints, biblical characters, or events from religious or mythological cycles. The tales create a connection between the past narrative and the situation of the patient or charm-user

3 The Prologue, or the in principio, was used in the Middle Ages by Mendicant Friars when begging, but it was also used as a charm to drive out demons, bad dreams, and even to cure epilepsy, often referred to as morbus Sancti Johannis. In the late twelfth century, Gerald of Wales stated that the ignorant people of his day believed that the in principio could exorcise demons. Giraldus Cambrensis, Opera, ed. J.S Brewer, Rolls Series, 1862, Vol II p 129. See also R.A Law in P.M.L.A Vol XXXVII (1922), 208-215 and E.G.CF Atchley in Trans. St Pauls Ecclesiol Soc., Vol IV (18961900), p 161-176.

${ }^{4}$ In both cases, the in principio is found among and between healing charms and medical remedies. Additionally, rather than being translated into Welsh, or written in Latin with Latin orthography, the in principio was written orthographically in Welsh, though it remained essentially Latin, a point I will return to later. Rather than translating it into Welsh, which would have been pretty standard for a religious work of that time, the text was kept in Latin, but written in Welsh orthography, transliterated, or transcribed, for or by someone unfamiliar with Welsh. The ways in which the text was transmitted in these instances, along with the manuscript context in which they are found, indicate quite clearly that they functioned as healing charms in both cases.

5 Social class was also a factor in Gwen's case, and, as Richard Suggett has demonstrated, it should be noted that Gwen would have most likely been allowed to live in peace and under the radar had it not been for the involvement of (and threat to) a wealthy local family. See SugGETt (2019) for more.

6 Scholars of Welsh history typically view the Laws in Wales 1535-1542 as the time of transition from medieval to early modern.

7 There is a fairly significant disparity between extant sources from the earlier period (late fourteenth century/early fifteenth century) and those of the later period (mid fifteenth century to the early modern era). Nevertheless, there is a discernible development in the Welsh charms, most notably in those that can be classified as "narrative charms". 
in the present. The power of a narrative charm lies in this perceived link between past and present, and the virtue and potency of the charm is in its ability to dissolve the boundaries between narrative past and present reality. In other words, the circumstances of narrative parallel the situation in the present and will affect the present through a sort of homeopathic magic. ${ }^{8}$ In the medieval narrative charms of Western Europe, the historiolae were often biblical or apocryphal episodes that became identified with a particular malady. For example, many charms to stop bleeding use the motif of the waters of Jordan standing still when Christ was baptized. The efficacy of this charm depends on the link between the power of the Christian imagery and the present condition of the patient. As Lea Olsan points out, healing charms in medieval Christianity are most often found when a primary feature of the ailment coincided with a culturally charged image that could be effectively expressed as a charm. A specific charm motif is associated with its symptom by a specific image or word - what Lea Olsan calls the "semantic motif" of a charm (OLSAN 2004). As she has pointed out in her work on verbal charms in England, the existence of a medieval charm (or prayer) to cure an ailment probably depends less on the inherent nature of the medical condition than on the cultural perceptions of the disease or symptom (ibid.). The ways in which charms are ingrained in cultural memory rely on the "indexical relationship" between symptoms associated with specific motifs that are used as a cure (ibid.). According to Olsan, the language of a charm enables the simultaneous representation of a sacred past, living predicament and future expectation (ibid. See also OlSAN 1992).

\section{WELSH MANUSCRIPT SOURCES AND CHARMING TRADITIONS}

Before examining specific Welsh charms, it will be useful to provide a very general context for Welsh manuscript production in the Middle Ages. The earliest manuscripts containing Welsh texts date from the middle of the thirteenth century. Before that, there are few examples of written Welsh, primarily found as marginalia and fragments. There are few early medieval manuscripts extant from Wales. No more than twenty manuscripts, including fragments, survive from Wales between the eighth and twelfth centuries. ${ }^{9}$ For the whole of the medieval period, it is estimated that only about 250 manuscripts survive from Wales, and only about 160 surviving manuscripts from that period are in Welsh (Huws 2000). These texts include the earliest collections of Welsh poetry, Welsh legal texts and prose. The period from 1250 to about 1400 resulted in approximately eighty books in Welsh, including fragments and incomplete books (Huws 2000:40). Of these eighty or so Welsh books, five feature significant medical writing: four are dedicated medical manuscripts, and another compilation of various Welsh material features large sections on medicine. It is almost entirely from these early medical books that we get our

\footnotetext{
8 For more on narrative charms see Bozóky 2013:101. Many thanks to both Lea Olsan and Katherine Hindley for several stimulating discussions of narrative charms in the Welsh and English traditions. The work of both of these scholars has informed my own work on the Welsh charming tradition.

9 ibid. The earliest surviving Welsh book is the $8^{\text {th }}$ century Gospel of St. Chad, at Litchfield Cathedral.
} 
earliest Welsh charms (prior to approximately 1400). ${ }^{10}$ We are thus slightly limited by the relatively small sample size of charms available to us in Welsh manuscripts before the mid-fifteenth century, at which point charms burst onto the scene, either due to an explosion in popularity, or an increase in the output of the types of manuscripts that included charms among their texts.

Most Welsh charms are found scattered throughout the pages of composite manuscripts that feature medical writing, along with religious prose and poetry, and other miscellanies. There are only two dedicated books of medicine that feature considerable collections of charms, and both of these manuscripts represent the two largest collections of Welsh charms in any manuscript from the period in question. ${ }^{11}$ One, Cardiff Ms. 3.242 (c. $1375-$ 1400), features a collection of about a dozen charms in Welsh, of which about half are narrative charms. These narrative charms include significant Latin text and use popular European narrative charm motifs such as Christ's crucifixion under Pontius Pilate (for tertian ague), Felix Apollonia (for toothache), and Longinus for bleeding. All of the Welsh charms of Cardiff Ms. 3.242, narrative or not, feature operative Latin words or phrases which derive from the Christian liturgy. This manuscript also features an equal amount of purely Latin charms with no headings or directions in Welsh. All of the Latin charms in this manuscript are narrative charms of the types common to medieval Europe and England. The second dedicated book of medicine to feature a significant collection of charms in Welsh is National Library of Wales Peniarth Ms. 204, a composite manuscript of several medical texts from the second half of the fifteenth century up to the midsixteenth century, all brought together in their current form at some point in the sixteenth century (Daniel Huws, unpublished book manuscript, accessed with the assistance of Catherine McKenna, Harvard University, and Canolfan Uwchefrydiau Cymreig a Cheltaidd Prifysgol Cymru, Aberystwyth.). The charms in this manuscript date from the early to mid-sixteenth century and are mostly narrative charms, though they are less similar to the commonly circulated narrative charms of medieval England and Europe.

For the most part, charms were copied into Welsh manuscripts in a seemingly indiscriminate manner. They were often included in sections that featured medical recipes, as would be expected, but they were also often dispersed among religious poetry and prose, or in whatever space would accommodate them in a given manuscript. However, they are less frequently included as marginalia, and when it is clear that they were added by a later hand, they are most frequently added onto unused pages at the beginnings and ends of quires. There are relatively few Latin-only charms in Welsh manuscripts. Most of them that use Latin as the primary language are at the very least tagged with a Welsh heading that alerts readers of the charm's purpose. Additionally, they most often feature closing directions in Welsh, pertaining to the practical application and/or performance of the charm. The charms often feature some minimal rubrication in which the tag or heading is featured in red ink. Most charms in Welsh manuscripts

10 There are a few late fourteenth-century charms found in later manuscripts, having at some point been bound with the later texts.

11 Here I consider a collection of ten or more charms to be a "significant collection". Most manuscripts with charms feature anywhere between one to five charms, and they are often not found in direct succession of each other as they are in the case of Cardiff 3.242 and National Library of Wales Peniarth Manuscript 204. 
feature large crosses between the operative words or phrases, which is fairly common in other charming traditions of medieval Western Europe. These crosses likely indicate the point at which the performer of the charm was meant to make the sign of the cross over the wound or person receiving it. On the whole, copyists seem less inclined to include these specific types of crosses in later Welsh manuscripts of the early modern era, at least as far as I have observed. Another notable feature of Welsh charms is the distinct lack of herbal medicine that accompanies the charm. In fact, I can recall only a few charms from the period in question that also feature herbal medicinal advice within the overall text of the charm. In manuscripts that feature charms and herbal remedies for the same ailments, it is uncommon to find them in direct succession.

Charm types vary among Welsh manuscripts from the medieval to early modern eras. Vernacular narrative charms are popular, as are verbal charms which feature operative words and phrases taken from the Christian tradition. Verbal charms for the bites of snakes and dogs, along with narrative and non-narrative charms fot toothache, narrative charms for bleeding and general blows and wounds are the most prevalent. There are a handful of complex charms for protection from the evil eye, bewitching or greed, along with charms for various other medical ailments, such as scrofula, abscesses on fingers or toes, and epilepsy. Interestingly, the narrative charms for epilepsy that exist in Welsh manuscripts are never in Welsh, but instead are written in English or Latin, and all include the Three Kings narrative motif. Generally, the charms of Welsh manuscripts are completely in the vernacular, or they are dual-language charms that display the heading and directions for practical application in Welsh, while the operative words are in Latin. There are relatively few English charms in Welsh manuscripts, and these tend to be exclusively for epilepsy or staunching blood. The majority of charms from medieval and early modern Wales focus on the staunching of blood from a wound, or the general healing of a wound. There has been only one published study of medieval Welsh healing charms: a very helpful general sampling, in Welsh, of a handful of charms and prayers found within medieval and early modern Welsh manuscripts (ROBERTs 1965). I hope that this paper will contribute in some small way, providing an overview of some of the most common narrative charm types in the Welsh tradition before the onset of the modern era.

\section{THE LONGINUS CHARM TYPE IN WELSH MANUSCRIPTS}

Of all the charms for blood loss and general wound healing, the most prevalently copied charm type was the Longinus motif, which was common in Western Europe and continued to be used well into the early modern and modern periods. ${ }^{12}$ This charm type is among the earliest Welsh examples of healing charms, and its transformation over time yields interesting insights into the changing function of the charm and the preferred use of the vernacular over Latin, which becomes most apparent from about the early-to-mid sixteenth century. The earliest extant Welsh Longinus charm is found in Cardiff Ms. 3.242, the late fourteenth-century medical manuscript briefly outlined above, which features two

12 While my focus is on Welsh healing charms up to about 1600 at the latest, Owen Davies has presented some fascinating charms circulating in Britain in a later era. For more see DAVIES 1996. 
large collections of charms: one in Welsh and one in Latin. ${ }^{13}$ In this manuscript, the Welsh charms are generally grouped together, as are the Latin, though the two collections are kept separate. While all of the Latin charms in this particular manuscript are narrative, only four of the vernacular Welsh healing charms conform to that genre.

\footnotetext{
"Rac gwaetlin o wythien mal o le arall ysgriuenna y geireu hynn: Longeus miles latus domini perforauit et continuo exiuit sanguis et aqua + In nomine patris stet sanguis + In nomine filii restet sanguis + In nomine spiritus sancti non exeat gutta. Ter fiet ista benedictio et restet sanguis." (Huws, unpublished.)
}

[For bleeding from a vein or from another place, write these words: the soldier Longeus pierced the side of the Lord and blood and water immediately flowed out + In the name of the father let the blood stop + In the name of the son let the blood stand firm + In the name of the holy spirit let not a drop escape. Thrice let this blessing be done and let the blood stop. $]^{14}$

As is fairly typical of the earliest healing charms in Welsh manuscripts, the charm uses Latin for the words of power, while the heading and the directions for the application of the charm are in the vernacular. What sets this charm apart from similar, contemporary Welsh-Latin charms is that the scribe did not revert to Welsh for the final directions pertaining to the recitation and practical use of the charm, which is the standard for such dual-language charms in Welsh manuscripts. This is one of the very few times in which the instructions are given in Latin, and it is notable that this manuscript features medical writing not only in Welsh, but in Latin and even Anglo-Norman French.

Another quite early Welsh example of the Longinus narrative charm is found in National Library of Wales Ms. Peniarth 47, which itself partly dates to the mid or late fourteenth century, though the charms, found on the last page of the manuscript, are likely fifteenth-century additions. This composite manuscript primarily features historical writing in Latin and Welsh. The charms are found alongside Welsh texts that focus on prophecy and instructions for diet and bloodletting. The Longinus charm here is unique, at least within the Welsh tradition, for its fusion to a purely Latin charm, also for staunching blood. The Latin charm uses the motif of Nicodemus pulling the nails from Christ's wound on the cross - the only known use of this motif in a Welsh manuscript - and is written entirely in Latin, including the heading and directions for application of the charm. On the page, the Nicodemus charm flows naturally into the Longinus charm, and it is only due to the rubricated Welsh heading added on the right margin beside the start of the Longinus text where we can discern that the scribe at least saw these as two separate charms, or at least separate components. While the Nicodemus charm is fully Latin, including the rubricated heading, the Longinus

13 For an edition and translation of this manuscript, see JoNEs (1955-1956), though she tends to omit significant parts of the charm texts, namely the "prayers" and "prayer-like" lines of the charms. More recently, Diana Luft has undertaken a new study of this manuscript and has generously shared some of her own transcriptions and translations for comparison. Additionally, the staff at the Cardiff Central Library, in particular Lesley Jenkins, graciously made the manuscript available for me to consult on very short notice.

14 All translations are my own. 
charm is rubricated via the Welsh marginal title rac gwaetlyn (for bleeding). The charm is then given in Latin, in the main body of text:

"Longius ebreus miles latus domini nostri jesu christ perforavit et continuo exivit sanguis et aqua. Sanguis redemtionis et aqua baptisivatis. In nomine patris + cessat sanguis + In nomine filiis restat sanguis + In nomine spiritus sancti amplius non exeat sanguis." (National Library of Wales Ms. Peniarth 47 iii, page 31.)

[The Hebrew soldier Longinus pierced the side of our Lord Jesus Christ and blood and water immediately ran out. The blood of redemption and the water of baptism. In the name of the father + the blood ceases ${ }^{15}+$ In the name of the son the blood stands firm + In the name of the Holy Spirit let the blood not run out any more.]

Immediately following, in the main body of text, is another rubricated heading entitled rac gwaetlyn hevyt (also for bleeding), which contains the typical Welsh directions concerning the application of the charm, including how many times to recite certain prayers.

"Rac gwaetlyn hefyt. Ysgrivenner wrth penn ywch y geireu hynn: $a+g+1+a$ teir gweith a thri phader a thri ave maria."

[Also for bleeding. Write on (the) forehead ${ }^{16}$ these words: $\mathrm{a}+\mathrm{g}+\mathrm{l}+\mathrm{a}$ three times and three Our Fathers and three Ave Marias.]

Although this seems like a possible additional charm, I read it as a continuation of the Latin charm above. In dual-language Welsh and Latin healing charms, the directions for the performance and application of the charm typically come after the operative Latin words of the charm. Most often these charms do not include special additional rubrication or distinction as seen in the charm above, although this does occur on a few occasions. It seems, however, that on this page the scribe was perhaps unable to distinguish the end of one charm and the beginning of the next, or it may suggest that such distinctions were of no real consequence to the scribe.

The Longinus charms above represent the earliest attested Welsh forms of such charms (late fourteenth and early fifteenth century). This is possibly the oldest Welsh version to associate the blood with redemption and the water with baptism or cleansing. The earliest Welsh Longinus charms are generally short, and use Welsh sparingly. Despite the heavy use of Latin operative words and phrases in many of these earlier Welsh charms, the Longinus motif is not found as a solely Latin charm, nor in an exclusively Latin context,

\footnotetext{
15 It is perhaps of note that this verb, in the Latin, and the following verb, were not given in the subjunctive, as was the case in the charm above (and as is the case in the last verb of this current charm). Perhaps this was simply a mistake on the part of the copyist or the text he may have been copying from, or perhaps it is indicative of the copyist's level of familiarity with Latin.

16 Or, 'above the head'.
} 
in Welsh manuscripts, as is the case with some other Latin narrative motifs. ${ }^{17}$ Rather, the earliest Longinus charms feature Welsh headings and instructions. However, the Welsh Longinus charm type undergoes a distinct change that seems to begin around the later fifteenth century and continues well into the sixteenth. An early sixteenth-century version of the Longinus charm type reads thus:

\begin{abstract}
"I stopio gwaed. Longyns marchoc evrddol ebrv a roddet i wayw ruddevydd yn i law I yllu stlus yr Arglwyd ni Iesu crist oni ddoedd frwd o waed ir yn prynv ni oni ddoeth frwd o ddwr er yn golchi ni. Da di waedd gwstadta di waed croes crist waed rag na roedtech di mwy .N. et postea dicat pater noster et ponit folium de vrtica in lesione: I ystopio gwaed vn supra." (National Library of Wales Ms. Llanstephan 10, page 15.)
\end{abstract}

[To stop blood. Longinus the dubbed Hebrew knight put his reddened lance in his hand to pierce the side of our Lord Jesus Christ, so that a stream of blood came out in order to save us, and so that a stream of water came out in order to cleanse us. Let your blood be good, let your blood stop. (By the) blood of Christ's cross, blood, do not run out more, N[omen]. And then let him say a Pater Noster and put a leaf of nettle in the wound: to stop blood above.]

This charm, which dates to the early sixteenth century, reveals the onset of the trend of rhetorical expansion and amplification of the Longinus narrative. Here, he is not referred to by the Latin title Longinus miles, but by the expanded Welsh epithet Longyns marchoc evrddol ebrv, 'Longinus the dubbed Hebrew knight'. The charm also expands the narrative pertaining to the piercing of Christ's side, and from this point onwards this charm-type always specifies that he pierced Christ's side with his reddened or bloody lance. Although this charm is representative of the ways in which Longinus charms began to change, there are a couple of aspects that are unique to it. It is extremely rare that a Welsh charm reverts to Latin from Welsh in order to present the instructions for the practical application of the charm. The Latin charm discussed earlier, from Cardiff Ms. 3.242, delivers the instructions in Latin, but since it is entirely in Latin, we might expect the directions to follow suit. In the sixteenth-century charm above, the copyist only uses Latin in order to instruct that certain prayers be said, along with an accompanying herbal prescription. Additionally, this is one of very few charms that offers any sort of herbal medicinal advice within the charm. It is found within a manuscript that consists mostly of medical writing, along with some religious prose and poetry. The text is almost entirely in Welsh, accompanied by a few pages of English medical recipes.

Longinus charms are routinely adapted and their general structure and forms develop throughout the sixteenth century, broadly displaying a distinct focus on the vernacular over Latin and a marked tendency for rhetorical expansion. Two Longinus charms, along with a shorter charm to stop bleeding that uses the Christ born in Bethlehem motif, are included in one manuscript from the second half of the sixteenth century, National Library

17 For example, some charm types only exist in Welsh manuscripts in Latin contexts. A Latin charm for an eye blemish features the only use of the Nichasius motif that I have thus far uncovered in Welsh. Similarly, the charms that feature Peter sitting on a stone, or in the gates of Galilee are specific Latin charms that were not, for whatever reason, featured in vernacular charms in Welsh manuscripts. 
of Wales Ms. 873b, a collection of religious and moral texts with some astrological and medical writing. The first Longinus charm reads:

"Llyma sswyn i stopio gwaed brath nai ddyrnod. Mi a y swyna y ty waed val yr ygorodd loyngyt farychoc yrddol o ebriw ar gwayw ryddefydd ar ysdlys Jesu Grist yn Harglwydd ni, oni a ddeth or brath ddwy frwd: un o waed er yn prynu ni ac un o ddwfwr er yn golychi ni. Yr wy yn gorychymyn iti, waed, ystopo. Yn enw y tad ar mab, na cherdda di, waed. Yn enw yr ysbryd glan nag ystoc, waed. Yn enw y tad a'r mab a'r ysbryd glan. A dwaid swyn hwnn tair gwaith a henwa y dyn i bo y waed yn kerdded a dod dy law ar y ben a dowaid v pader a ffymp afi mareia a chredo er yn rydedd yr pymp archoll prynysinal a ddioddefodd yn harglwydd ni jesu grist er tyny enaid dyn o kaethiwed yffern.” (National Library of Wales Ms. 873b, page 35.)

[Here is a charm to stop blood from a bite or blow. ${ }^{18}$ I charm you, blood, just as Longyt (Longinus) the dubbed Knight from Israel cut the side of our Lord Jesus Christ with the reddened lance, until two streams came from the wound: one of blood in order to redeem us and one of water in order to cleanse us. They command you, blood, to stop in the name of the father, and [in the name] of the son do not flow, blood. In the name of the holy spirit do not stir, blood. In the name of the father and of the son and of the holy spirit, and say this charm three times and name of the person whose blood is flowing and bring your hand upon his head and say five Our Fathers and five Ave Marias and a Chredo in honour of the five redeeming wounds and the suffering of our Lord Jesus Christ in order to pull the soul of man from the bonds of hell.]

Later in the same manuscript, the scribe provides a similar version of this charm.

"Llyma swyn ysdopio gwaed dyn. Mi a swyna i ti waed val yr atores lownyslo farchoc yrddol or briw ar gwayw ryddefydd ar ystlys Jesu Grist yn harglwydd. a fond addoeth or brathay ddwy ffrwd, un o waed er yn pryny ar un llall er yn golychi mi, a orychmyna iti waed ystopio yn enw y tad ar mab ar ysbryd glan nac ystoc wayd, yn enw y tad ar mab ar ysbryd glan. A dowaid y swyn yma dair gwaith a henwi y dyn y bo y waed yn kolli a rhoi i law ar y ben a dwedyd v pader a ffym afi mareai er anrydedd yr $\mathrm{v}$ arycholl pen a oedd ai gorff yn harglwydd ni jesu grist er tyny enaid dyn o yffern." (National Library of Wales Ms. 873b, page 251.)

[Here is a charm to stop blood of a man. I charm you, blood, just as Longinus the dubbed knight from Israel pierced the side of our Lord Jesus Christ with his reddened lance. And from the wounds came two streams, one of blood in order to redeem us and another in order to cleanse us. And I command you, blood, to stop, in the name of the father and of the son and of the holy spirit. Do not stir, blood, in the name of the father and of the son and of the holy spirit. And say the charm here three times and name the man whose blood is flowing and put your hand upon his head and say five Our Fathers and five Ave Marias in honour of the five wounds when they were upon the body of our Lord Jesus Christ in order to pull man's soul from hell.]

18 Both words used here indicate a wound from which the skin is pierced. Brath means bite, but also a piercing or stabbing. Similarly, dyrnod means a blow, but in the sense of a cut or gash-a blow that significantly pierces the skin. 
Both of these charms include a direct adjuration to the blood while continually identifying and addressing the blood. Additionally, these charms explicitly identify themselves as a charm (swyn) in the heading, and they use the verb swyno, 'to charm', whereas earlier charms do not typically call themselves a charm or use vocabulary that specifically relates to charming. By the early sixteenth century, charms typically identify themselves as such, using swyn, and their language tends toward threatening or challenging the disease or its cause, differentiating themselves from earlier ones. These changes coincide with a linguistic shift as well, and at this point they most often tend to be transmitted entirely in Welsh, with very minimal Latin.

From the later fifteenth century and well into the sixteenth century, Welsh narrative charms consistently show signs of rhetorical expansion and/or vernacularization. A final example of a Longinus charm from around the second half of the sixteenth century is found in National Library of Wales Ms. Peniarth 204, a Welsh manuscript featuring medical texts from the fifteenth and sixteenth centuries. This charm was added to the first empty pages of the manuscript by a sixteenth-century scribe.

\begin{abstract}
"Llyma swyn y stobio gwaed brath nev i ddynion. Gwnaf i iti, waed, fal ir agores lonsivr y marchog vrddol dall o wlad yr Ebriw a'r gwaiw ruddefvdd yn ystlyss Iesu Grist yn harglwydd ni yni ddoeith dwy ffrwd, vn o waed er yn pryni ni ag vn o ddwr er yn golchi ni. Gorchymvn iti, waed, estobio yn enw'r dad, yn enw y mab. Na cherdda di, waed, yn yr Ysbryd Duw Glan. Nac ysgog di, waed, nag o gig nag o gnawd nag o ie nag o with. Yn enw dad, yn enw a'r mab a'r ysbryd dyw glan. A dowed y swyn yma deir $r$ gwaith a heward yn y bor(e) swyn iddo y waed yn kolli a dyrro dy law ar i ben o byddi di yn gallu krydda ef a dowaid v bader a ffumb afi meria er anrydedd yr v archoll llydan a ddioddefodd yn harglwydd y ni iesv grist er brynv yr holl cristynogion y byd amen.” (National Library of Wales Ms. Peniarth 204, page 1.)
\end{abstract}

[Here is a charm to stop blood from a wound upon people. I will do to you, blood, just as Lonsiur (Longinus) the blind dubbed knight from the land of Israel pierced the side of our Lord Jesus Christ with the reddened/bloody lance, so that two streams came, one of blood in order to redeem us and one of water in order to cleanse us. I command you, blood, to stop in the name of the Father. In the name of the Son, do not flow, blood. In [the name of] the Holy Spirit of God, do not stir, blood, not from flesh nor from skin nor from tendons nor from veins. In the name of the Father, in the name of the Son, and the Holy Spirit of God. And say this charm three times with care in the morning. A charm for blood loss. Thrust your hand on his head if you are able to touch him and say five Our Fathers and five Ave Marias in honour of the five extensive wounds that our lord Jesus Christ suffered in order to redeem all the Christians of the world, Amen.]

This charm is one of the earliest Welsh examples I have found that mentions the tradition of Longinus being blind. It also displays the propensity for rhetorical expansion that was so common to this time. These sixteenth-century charms stand in sharp contrast to the earliest Welsh manuscript Longinus charm. Typical of later medieval Welsh charms, this one features direct addresses, conjurations, and adjurations to the malady - in this case, the blood flowing from the wound. The rhetoric of this charm threatens the wound, and the central speech act becomes the command to the malady or source of disease, along with the rhetoric of the narrative itself, which links the religious past to the reality of the present. 


\title{
THREE GOOD BROTHERS, FLUM JORDAN, AND CHRIST BORN IN BETHLEHEM
}

Although the Longinus motif is the most commonly used charm type for blows and wounds found in Welsh manuscripts of the later Middle Ages and through the onset of the early modern period, there are numerous examples of other popular motifs for stopping blood and for general wounds which include the Three Good Brothers Motif, Flum Jordan, and Christ born in Bethlehem. I have found two examples of the Three Good Brothers charm in Welsh manuscripts from the period in question. The following version comes from National Library of Wales Llanstephan Ms. 2, a mid-fifteenthcentury manuscript of religious, didactic, and narrative prose. The charms however, are likely from the end of the fourteenth century. ${ }^{19}$

\begin{abstract}
"O dri broder da pa le yr ewch chwi. Ni a awn heb wynt y uynyd olivet y geffiaw llysseuod y iacha braetheu. O dri broder da ymchwellwch dracheuyn a chymerwch oel wlyf ag wlan du a gwyn wy a dodwch wrth y bratheu a dywedwch yswyn hwnn. Mi a thynghedaf di vrath drwy rat a grym y pump archoll y rai a vuant yngwir diw ag wir ddyn ac ae kym[er]th yn y santeidia gorff er yn prynu ni. A[c] er y bronnau y rai aduneist di iessu gr[ist] hy[d] na doluryo ac na ddrewo ac na vo dr[wg] arogleu gan y brath hwnn mwyn noc y gan dy vratheu iessu grist namyn byt iachedic megis yr yachassant dy vratheu di iessu grist. Yn enw y tat ar mab ar ysbryt glan. A chanet tri phader er enryded yr goronn drayn + [ ] ben yr arglwd [remainder has either been erased or is heavily faded." (National Library of Wales Ms. Llanstephan 2, page 346-347.)
\end{abstract}

[O three good brothers where are you going. We are going, they said, to Mount Olivet to get herbs that heal wounds. O three good brothers, turn back, and take olive oil and black and white wool and put them on the bites and say this charm.

I adjure you, wound, by the grace and strength of the five wounds that were upon the true God and true man, which he received in his most holy body in order to redeem us. And by the breasts that suckled you, Jesus Christ, let this wound not hurt nor rot nor putrefy anymore than your wounds did, Jesus Christ, but let it be healed just as your wounds, Jesus Christ. In the name of the father and of the son and of the holy spirit. And sing three Our Fathers in honour of the crown of thorns $+[$ ] head of the lord...]

The last lines of the charm have either been erased or have faded heavily. Situated between a dual-language charm in Welsh and Latin for a whitlow or felon and a Latin Petrus Super Petram charm type for fever, this charm interestingly specifies that it should be sung or chanted. The Welsh verb here is canu, and though its primary meaning is 'to sing', it can also mean 'to chant, intone', and even 'to say' and 'to compose' (Geiriadur Prifysgol Cymru, available online at http://www.geiriadur.ac.uk.). Both Welsh examples of a Three Good Brothers charm use canu, and to my knowledge they represent the only two examples of Welsh charms using this verb. The two charm variants are nearly identical, with the only real variations appearing at the beginning and end of the charm.

19 Huws, Daniel unpublished book manuscript, accessed with the assistance of Catherine McKenna, Harvard University, and Canolfan Uwchefrydiau Cymreig a Cheltaidd Prifysgol Cymru, Aberystwyth. 
The second version, from the fifteenth century, begins by identifying itself explicitly as a charm (swyn), and goes on to explain that it was made by Jesus Christ and shown to the three brothers. This version of the charm comes at the end of a section of religious prose consisting mostly of hymns and prayers to certain saints. The use of the verb саnu is interesting in this context as the hymns and prayers in the texts surrounding the charms would have had a natural emphasis on singing or chanting. Additionally, given its content, this charm, which says it was made by Jesus himself, fits well into a series of hymns and prayers.

Both manuscripts that feature a Three Good Brothers charm also feature a charm for a whitlow or felon. Both versions of this charm are also virtually identical, although the fifteenth-century version displays an interesting variation that encapsulates the shift in attitude towards the use of vernacular in charms. While the fourteenth-century charm for a whitlow or felon is overall shorter and more direct, featuring a fair amount of Latin, the early fifteenth-century version stipulates that it can be done in Latin or Welsh. This slightly later version displays the typical expansion and emphasis on the vernacular over Latin, though it does include a handful of Latin words and corrupt phrases.

Other narrative charms for bleeding and wounds commonly found in Welsh manuscripts include the motifs of Christ's birth in Bethlehem and his baptism in the river Jordan. National Library of Wales Ms. $873 \mathrm{~b}$ also presents an additional charm to stop blood. This charm follows the Longinus charm, but its title suggests it was conceived as a completely separate charm, rather than an extension of the Longinus charm.

\footnotetext{
"I attal gwaed. Gwna groes ar gyfer y gwaed drwy y geiriay hyn yn enw y tad ac velly kyn wired ageni jesu ymethlem ai vedyddio yn yrddonen ac val y safodd y dwr sa dithe ac nag yscoc waed yn enw gwelie yr arglwydd yn enw y tad ar mab ar ysbryd glan." (National Library of Wales Ms. 873 b page 36.)
}

[To stop blood make a cross over the blood together with these words: in the name of the father and thus as truly as Jesus was born in Bethlehem and was baptized in the Jordan and just as the water stood still, so (shall) you, and do not stir, blood, in the name of the wounds of the lord, in the name of the father and of the son and of the holy spirit.]

This charm does not explicitly instruct the user to speak or write, but it seems likely that the words were meant to be spoken as the sign of the cross was being made over a bleeding wound. A similar charm is found in National Library of Wales Ms. Peniarth 53, consisting primarily of a collection of Welsh and English poetry from the late fifteenth century.

\footnotetext{
"Y stopi gwayd. Yn gynta gwna groes ar yr archoll gan ddywedyd y fendith honn; jn nomine Patris et Filij etc. Kyn gywired ac y ganed Mab Dyw ym Bethelem ac y bedyddywyd yn dyfwr Jordan a chyn gywired ac y safwys y dyfwr, saf dithey waed. Jn nomine Patris etc., a dyweid pump Pader pymp Ave Maria a thr[ ] er ynrydedd yr pump archoll gan veddyleid am y ddioddei[feint]." (National Library of Wales Ms. Peniarth 53, page 83.)
}

[To stop blood. First make the [sign of the] cross upon the wound while saying this blessing: in the name of the Father and Son etc. As truly as the Son of God was born in Bethlehem and was baptized in the water of the Jordan and as truly as the water stood [still], thus [shall] your blood. 
In the Name of the Father etc. and say five Our Fathers, five Ave Maria and three [ ] in honour of the five wounds while thinking of his suffering.]

This charm fuses the motifs of Christ's birth in Bethlehem and his baptism in the River Jordan, drawing parallels between the stopping of the waters of Jordan and the stopping of the patient's blood. It creates a link between the veracity of Christ's birth in Bethlehem and the veracity and efficacy of the charm. This charm is shorter than contemporary Longinus charms, but I have found that the charms which use the motifs of Christ's birth or Baptism do not tend to appear in the very early manuscripts with charms. Additionally, the narrative does not undergo the same amount of expansion that the Longinus narrative experiences. These shorter charms for stopping blood also tended to be copied in Welsh, with very minimal Latin, if any at all.

One of the most fascinating Welsh narrative charms for stopping blood features the fusion of the Longinus and Flum Jordan motifs, which was common in medieval Europe, but not as prevalent in Welsh manuscripts. The charm, from the late fifteenth or early sixteenth century, begins in Welsh with the identifying heading, and similarly ends in the vernacular with directions for the recitation of the prayers, yet the majority of the charm is Latin. Although the presence of a dual-language charm is quite common, what makes this one stand out is that although it is Latin, it is written, orthographically, as Welsh.

\footnotetext{
"Llyma swyn i attal gwaed [ ]us miles ebreus latus [ ]cia perfforavyth ieth [ ] sewyth sangwius [ ]wnys ieth akwa baptysmatys yn nomyni pa + trys ieth fy + liei ieth ysbrytys + sawntei amen yn nomyni pa + trys sessyth sangwivs yn nomyni fy + liei ysbrytus + sawntei non ecsiath sangwius kweia kridimws koth sawnta maria mater domynei nostrei jessuw kristi viri ynfontem genuwyth jesswm krystwm + ieth seikwth restityth akwa jordanys kwan babtyssatus iest jessus krystus sic tvwi vini kwi sangweini sunt plini yn nomyni pa + trys ieth fy + liei ieth ysbrytus + sawntei Amen. a dyw[aid] dri fader a thri Avi Maria." (National Library of Wales Manuscript Peniarth 205, page 8-9.)
}

[Here is a charm to stop blood. [Login] us the Hebrew soldier pierced the side [of Christ with his spear] and [ ] the blood [of redemption] and the water of baptism. In the name of the father + let the blood cease. In the name of the son + and holy spirit + let the blood not run out. We believe that Saint Mary (was) the mother of our Lord Jesus Christ, (and) truly bore the infant Jesus Christ + and thus as the water of the Jordan stood still when Jesus Christ was baptized, so too shall your veins and blood be full, in the name of the father + and the son + and the holy spirit + Amen. And say three Our Fathers and three Ave Marias.]

This is not the only case in which a Welsh manuscript presents a charm in Latin using Welsh orthography. There are, to my knowledge, at least two other instances - both straddling the divide between the end of the fifteenth and the beginning of the sixteenth centuries - in which charm texts were written out in this unique orthography. In both cases, the in principio of the Gospel of John was used as a charm, and the Latin of the text was written using Welsh spelling and orthographic conventions. Although texts of the gospels were translated into Welsh, when they existed in a way that indicates they functioned as a charm, it appears that they would more commonly remain linguistically Latin, but written using Welsh orthographical conventions. Perhaps the scribes here were 
trying to create an element of mystery or esoteric secrecy (though admittedly this is pure speculation). The more likely case, however, was that these unique texts circulated in a context in which some users would not have known Latin, and would therefore have needed a guide to pronounce the Latin words of the charm correctly. Texts such as these can provide valuable clues regarding the attitudes or anxieties over using Latin versus the vernacular in texts that were used for healing (in addition to providing scholars with insights into how Latin was pronounced in fifteenth/sixteenth century Wales). These texts are undeniably Latin, but circulated in a context in which readers or users would not have known Latin and would have had no access to formal training in the language.

\section{CONCLUSIONS}

Although narrative charms exist in Welsh for other common ailments such as fever, toothache, scrofula, and even protection against the evil eye, bewitching, and greed, the most common ones are those intended to stop bleeding and to heal general blows and wounds. An analysis of the charms presented in this essay uncovers several observations that might allow for insights into the changing social contexts surrounding traditions of healing and charming. If we consider the ways in which the scribes referred to the charms themselves within the texts, an interesting pattern emerges. Almost none of the earliest charms of the fourteenth and early fifteenth centuries specifically refer to themselves as such. Instead, they begin with the same brief, formulaic opening as the herbal remedies: Rac $x$ (Against $\mathrm{x}$ ), or, $i x$ (for $\mathrm{x}$ ). By the mid sixteenth century, charms were more commonly labelled using the formula llyma swyn (here is a charm), and sometimes even llyma gweddi (here is a prayer). This demonstrates the degree to which healing charms encompass elements of magic, religion, and science, while also highlighting the ambiguous nature of the boundaries between these spheres and drawing attention to the problematic nature of any attempt to strictly define such categories.

The narrative charms, in Welsh, for stopping blood and healing wounds, are fairly consistent with other traditions in English and Latin, especially in the fourteenth and fifteenth centuries. The earliest manuscripts use Latin in a way that is consistent with charming traditions throughout medieval England and Europe. Often, the charm begins in the vernacular, describes what the charm is effective against, and sometimes gives specific instructions to prepare various medical potions or ointments, though that is typically not the case with Welsh charms, which almost never offer any herbal medical advice within a charm. Then the user of the charm is instructed to write or say certain operative rhetorical units that contain within them the power to heal. These words can narrate a specific historiola, or they can be strings of alliterative or rhyming words rooted in Christian tradition (or sometimes the traditions of other religions). The operative words are most often presented in Latin or Latinate forms. Welsh charms from the fourteenth and fifteenth centuries tend to follow this pattern. However, there is a noticeable departure, starting around the beginning of the sixteenth century and becoming most noticeable by the mid sixteenth century, at which point the charms are most often found completely in Welsh with no Latin. Along with the shift from Latin to the vernacular, we see a shift in the focus from writing to speaking. In general, dual-language Welsh-Latin charms that favour Latin tend not only to be shorter, but also to focus on the written word as part of the practical application of the charm. When 
the charms are entirely or mostly in the vernacular, they most often specify that something should be spoken rather than written. When they emphasize or feature Latin more heavily, they nearly always instruct the user to write (see Appendix One).

The record of very early Welsh charms is scant, and unfortunately the sample size of early Welsh charms (in Latin as well as the vernacular) is not large enough to pinpoint a more specific date for vernacularization. However, it is clear from the extant evidence that the late fifteenth century is important in the copying and transmission of Welsh charms. As the process of the vernacularization of the charms gets underway, they undergo expansion of the rhetoric surrounding the religious narrative incident, along with an increased preference for Welsh over Latin, often losing the Latin entirely. The operative words of the narrative charms are the words of the narrative itself, not the Latin of earlier charms, and their power is derived from those words and from the prayers that the charm instructs the user to say. ${ }^{20}$

Although my conclusions regarding the significance of this shift are preliminary, it is worth noting that this increasing preference for the vernacular in Welsh charms, especially those that feature religious narrative or references, coincides with the earliest translations of the Bible into Welsh and a generally increasing interest in the vernacular at a time when the use of Welsh in any official capacity had been expressly prohibited by England in Acts of Parliament from 1535 and 1536. However, Protestant Humanist efforts in Wales during the mid sixteenth century led to the first Welsh publication of the New Testament and Book of Common Prayer in 1567 and the first complete translation of the Bible in Welsh in 1588. It is within this context of social and religious change, and an increased concern with the vernacular, that we see the most drastic development in Welsh healing charms. From this time on, the charms become distinctly more "Welsh", possibly in response to the severe restrictions placed upon the use of the Welsh language by England. An in-depth study of the Welsh healing charms and how they use language can shed light on the tensions between not only Welsh and Latin, which is often perceived as the more learned language, but also between English and Welsh. The shift from these stark dichotomies to the primacy of the vernacular can further illuminate the nuanced tensions between England and Wales during various periods of social, political, and religious reform. Conversely, it can also highlight the ways in which the rich network of textual transmission and exchange continued across the Anglo-Welsh border.

$\overline{20}$ Welsh narrative charms that belong to the wider English and European tradition (Longinus, Flum Jordan etc.) often do not feature the elaborate strings of operative words or phrases that are sometimes labelled as 'gibberish'. Rather, in Welsh charms, these long strings of words and phrases are most prevalent in charms of general protection and in charms for ailments where the charm type does not display much continuity or consistency with wider charming traditions outside of Wales. 


\begin{tabular}{|c|c|c|c|c|c|c|c|c|c|c|c|c|}
\hline 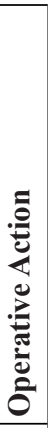 & 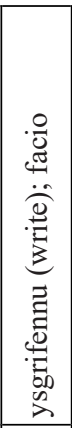 & 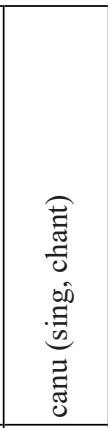 & 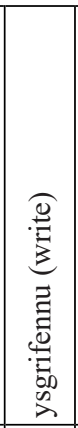 & 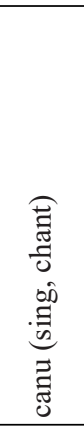 & 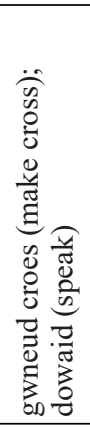 & 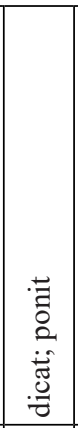 & 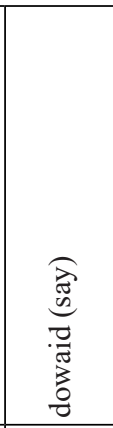 & 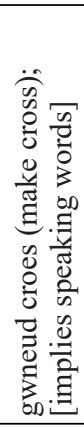 & 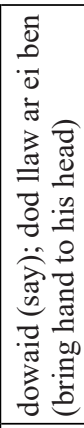 & 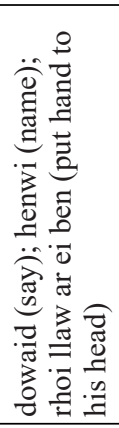 & 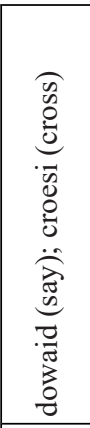 & 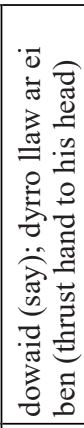 \\
\hline : & 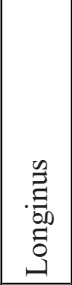 & 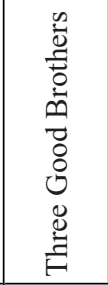 & 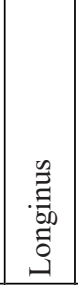 & 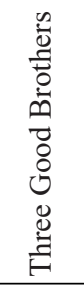 & 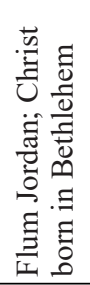 & 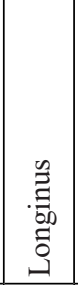 & 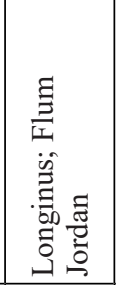 & 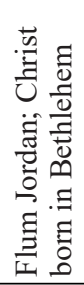 & 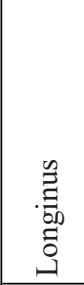 & 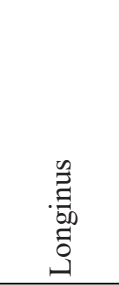 & 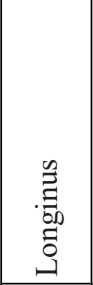 & 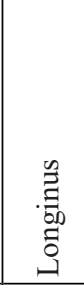 \\
\hline 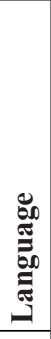 & 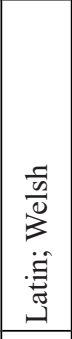 & $\frac{\frac{n}{n}}{0}$ & 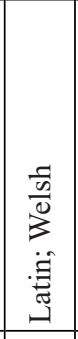 & $\frac{\frac{5}{5}}{0}$ & $\frac{\frac{n}{n}}{0}$ & 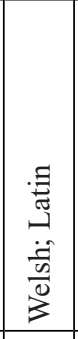 & 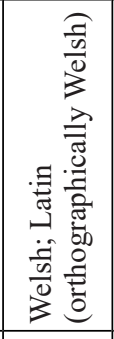 & $\frac{\frac{1}{0}}{0}$ & $\frac{\frac{5}{5}}{0}$ & $\frac{\frac{n}{n}}{0}$ & $\frac{\frac{n}{n}}{0}$ & $\frac{\frac{n}{n}}{0}$ \\
\hline : & 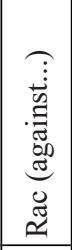 & 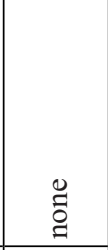 & 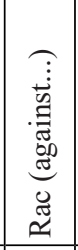 & 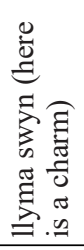 & $\stackrel{\overbrace =}{\underline{\vdots}}$ & $\stackrel{\overbrace{}}{\stackrel{\vdots}{0}}$ & 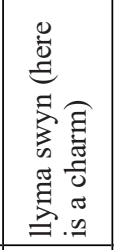 & 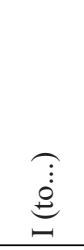 & 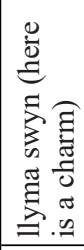 & 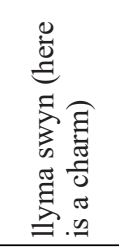 & 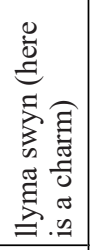 & 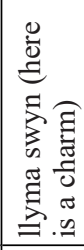 \\
\hline 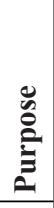 & $\begin{array}{l}\overrightarrow{0} \\
\frac{0}{0} \\
\frac{7}{0} \\
\vdots \\
\frac{\tilde{J}}{\omega}\end{array}$ & 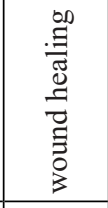 & $\begin{array}{l}\overrightarrow{0} \\
0 \\
0 \\
0 \\
0 \\
0 \\
\Xi \\
\text { 恶 }\end{array}$ & 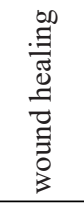 & 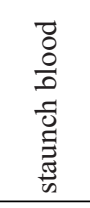 & 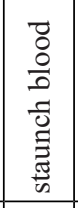 & 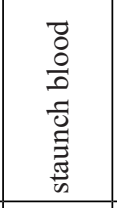 & 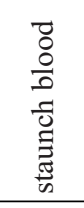 & 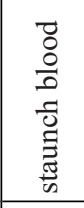 & 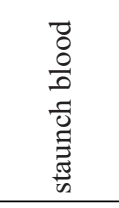 & 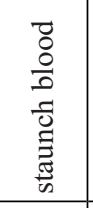 & 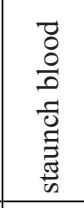 \\
\hline 气ี & \begin{tabular}{ll}
1 & \\
$n$ & \\
$n$ & 8 \\
\hdashline & 8 \\
$ن$ & \pm \\
\end{tabular} & 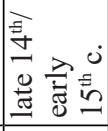 & 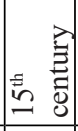 & 总 & 点 & $\begin{array}{l}n \\
n \\
0 \\
0\end{array}$ & 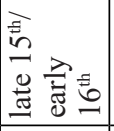 & E0 & $\begin{array}{l}0 \\
\tilde{E} \\
E\end{array}$ & $\begin{array}{l}0 \\
\pm \\
\dot{E}\end{array}$ & 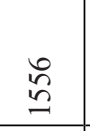 & $\begin{array}{l}0 \\
E_{0}\end{array}$ \\
\hline 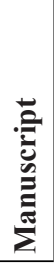 & 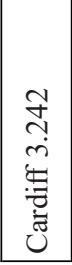 & 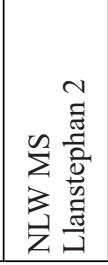 & 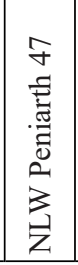 & 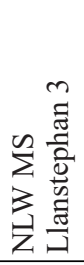 & 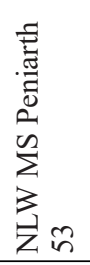 & 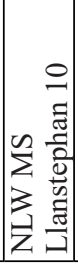 & 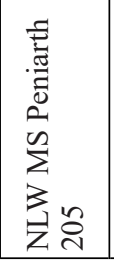 & $\begin{array}{l}0 \\
\infty \\
\infty \\
n \\
n \\
z \\
z\end{array}$ & $\begin{array}{l}0 \\
\infty \\
\infty \\
\infty \\
\sum \\
3 \\
z\end{array}$ & $\begin{array}{l}0 \\
\infty \\
\infty \\
\sum_{2} \\
3 \\
z\end{array}$ & 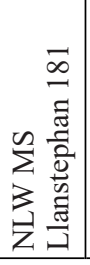 & 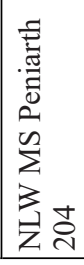 \\
\hline
\end{tabular}




\section{REFERENCES CITED}

ATCHLEYA, E.G.CF

1896-1900 Some Notes on the Beginning and Growth of the Usage of a Second Gospel at Mass. Trans. St Pauls Ecclesiol Soc., Vol IV, 161-176.

BozókY, Edina

2013 Medieval Narrative Charms. In KAPALÓ, James Alexander - Pócs, Éva - RYAN, W. F. (eds.) The Power of Words: Studies on Charms and Charming in Europe, 101-115. Budapest - New York: Central European University Press.

DAVIES, Owen

1996 Healing Charms in Use in England and Wales. Folklore 107:19-32.

1998 Charmers and Charming in England and Wales from the Eighteenth to the Twentieth Century. Folklore 109:41-53.

Huws, Daniel

2000 Medieval Welsh Manuscripts. Cardiff: University of Wales Press.

2008 The Welsh Book. In Morgan, Nigel J. - Thomson, Rodney M. (eds.) The Cambridge History of the Book in Britain. II. 1100-1400., 390-396. Cambridge: Cambridge University Press.

JONES, Ida B.

1955-1956 Hafod 16: A Mediaeval Welsh Medical Treatise. Études Celtiques 7:46-75, 270-339; 8:66-97, 346-393.

LAW, Robert Adger

1922 “In Principio". P.M.L.A Vol. XXXVII, 208-215.

OlsAN, Lea

1992 Latin Charms of Medieval England. Oral Tradition 7:116-142.

2004 Charms in Medieval Memory. In Roper, Jonathan (ed.) Charms and Charming in Europe, 59-88. Houndmills - Basingstoke - Hampshire - New York: Palgrave Macmillan.

2009 The Corpus of Charms in the Middle English Leechcraft Remedy Books. In Roper, Jonathan (ed.) Charms, Charmers and Charming: International Research on Verbal Magic, 214-237. Houndmills - Basingstoke - Hampshire - New York: Palgrave Macmillan. (Palgrave historical studies in witchcraft and magic.)

2011 The Three Good Brothers Charm: Some Historical Points. Incantatio. An International Journal on Charms, Charmers and Charming 1:47-78.

2013 The Marginality of Charms in Medieval England. In KaPALÓ, James Alexander - Pócs, Éva - Ryan, William F. (eds.) The Power of Words: Studies on Charms and Charming in Europe, 135-164. Budapest - New York: Central European University Press.

RoBerTs, Brynley

1965 Rhai Swynion Cymraeg. The Bulletin Board of Celtic Studies 21:197-213.

ROPER, Jonathan

2004 Charms and Charming in Europe. Houndmills - Basingstoke - Hampshire New York: Palgrave Macmillan. 
ROPER, Jonathan (ed.)

2005 English Verbal Charms. Helsinki: Suomalainen Tiedeakatemia. (FF communications 288.).

2009 Charms, Charmers and Charming: International Research on Verbal Magic. Houndmills - Basingstoke - Hampshire - New York: Palgrave Macmillan. (Palgrave historical studies in witchcraft and magic.).

SugGeTt, Richard

2008 A History of Magic and Witchcraft in Wales. Stroud: The History Press.

2019 Welsh Witches: Narratives of Witchcraft and Magic in $16^{\text {th }}$ and $17^{\text {th }}$ Century Wales. Wales: Atramentous Press.

Katherine Leach will receive her doctorate in May 2020, from the Department of Celtic Languages and Literatures at Harvard University, where she is also a Residential Tutor in Pforzheimer House. Before Harvard, she completed an MA in Medieval Welsh Literature from Aberystwyth University, Wales; as well as a BA in Classics from Hunter College (City University of New York). Her doctoral dissertation focuses on the never-beforepublished corpus of pre-modern healing charms in Welsh manuscripts. At Harvard she has taught for the department of Classics (Classical Mythology), the Celtic department (Beginning and Intermediate Modern Welsh; Celtic Mythology; Shape-shifters in Celtic Literature), and the department of Folklore \& Mythology (Performance, Tradition, and Cultural Studies: An Intro to Folklore; and The History of Witchcraft and Charm Magic). Her research interests include the intersection of medicine, magic, and religion in premodern Britian, as well as knowledge exhange between Wales and England (as well as continental Europe). E-mail: katherineleach@fas.harvard.edu 